\title{
Interpretasi Yosua 6:1-27 tentang Penumpasan Kota Yerikho terhadap Kekerasan Atas Nama Agama
}

\author{
Paul Cakra
}

Sekolah Tinggi Agama Kristen Negeri Toraja, Tana Toraja, Sulawesi Selatan paulcakra@gmail.com

\begin{abstract}
The reality of violence is a reality in relationship that has never disappeared from human life, the triggers also vary, ranging from personal issues, politics, economic culture, even religion. Violence is an action that always results in a bad impact for those who are the object of violence, so that it is not expected to exist in human relations. Furthermore, it cannot be denied that religion is one of the causes of violence, this is caused by various factors, one of which is the problem is about interpretation of the biblical text's, so that it is necessary to study or interpret the biblical text with the right approach. The description in this research will focus on Joshua 6:1-27 with a narrative criticism approach which is certainly supported by other approaches such as historical criticism and grammatical criticism. So that through this study it will lead to an understanding that the story of the destroyed carried out by Joshua and the nation of Israel is a legitimate act because they acted on God's command. So that Joshua's actions cannot be classified as acts of violence in the name of religion.
\end{abstract}

Keywords: destroyed; Jericho; Joshua 6; violence of religion

\begin{abstract}
Abstrak: Realitas kekerasan adalah realitas dalam hubungan yang tidak pernah lenyap dari kehidupan manusia, pemicunya pun beragam, mulai dari masalah pribadi, politik, budaya ekonomi, bahkan agama. Kekerasan adalah tindakan yang selalu menghasilkan dampak buruk bagi mereka yang menjadi objek kekerasan, sehingga tidak diharapkan ada dalam hubungan manusia. Lebih jauh, tidak dapat dipungkiri bahwa agama adalah salah satu penyebab kekerasan, hal ini disebabkan oleh berbagai faktor, salah satunya adalah masalah penafsiran teks Alkitab, sehingga perlu dipelajari atau ditafsirkan teks Alkitab dengan pendekatan yang tepat. Deskripsi dalam penelitian ini akan berfokus pada Yosua 6:1-27 dengan pendekatan kritik naratif yang tentu saja didukung oleh pendekatan lain seperti kritik sejarah dan kritik gramatikal. Sehingga melalui penelitian ini akan mengarah pada pemahaman bahwa kisah kehancuran yang dilakukan oleh Yosua dan bangsa Israel adalah tindakan yang sah karena mereka bertindak atas perintah Tuhan. Sehingga tindakan Yosua tidak bisa digolongkan sebagai tindakan kekerasan atas nama agama.
\end{abstract}

Kata kunci: Joshua 6; kekerasan agama; penghancuran; Yerikho

\begin{tabular}{llll}
\hline Article History : & Received: 06-11-2019 & Revised: 12-12-2019 Accepted: 17-12-2019
\end{tabular}

\section{Pendahuluan}

Hidup aman, damai dan sejahtera merupakan contoh dari ajaran agama yang juga merupakan dambaan setiap insan di dunia. Hidup yang diwarnai dengan perilaku violent seperti kebencian, dendam, permusuhan, dan sebagainya diharapkan untuk 
selalu hilang dan menjauh dari kehidupan setiap insan. Yewangoe pernah mengatakan bahwa "agama-agama dianugerahkan kepada manusia untuk menyampaikan cinta kasih dari Tuhan yang harus kemudian direfleksikan dengan semua ciptaan-Nya”. Semua agama ataupun kepercayaan di dunia ini, tidak ada satupun yang menekankan penganutnya untuk mempraktekkan tindakan kekerasan, justru sebaliknya, semua agama menginginkan yang namanya perdamaian. Memang, secara apologis sangat mudah mengatakan bahwa kandungan agama-agama pada dasarnya adalah non-violent dan manusialah yang baik individu atau kelompok yang menyelewengkan maknanya. Jika diperhatikan, maka akan ditemukan bahwa tidak semua kekerasan di dunia ini berbasis keagamaan, namun dalam realitas yang ada, justru kekerasan bernuansa agama yang kemudian banyak ditemukan.

Kekerasan atas nama agama selama berabad-abad merupakan kejahatan terburuk yang telah mengisi peradaban manusia. Di Indonesia misalnya, kekerasan atas nama agama sudah terjadi dan mengukir luka yang serius bagi bangsa ini. Contoh deretan kekerasan bernuansa agama adalah, pemberontakan DI/TII yang terbentuk di Jawa Barat tahun 1948 dengan tujuan untuk mendirikan negara Islam, pembakaran lima gedung gereja di Situbondo tahun 1996, kerusuhan di Poso tahun 1998, kerusuhan di Maluku Utara tahun 1999, konflik pembakaran masjid oleh para jemaat Gereja Injili di Tolikara tahun 2015, dan sebagainya. Dengan melihat peristiwa-peristiwa di atas, dapat dikatakan bahwa hal ini merupakan sesuatu yang paradoks karena agama mengajarkan nilai-nilai luhur, tetapi agama juga bertanggung jawab terhadap terjadinya kerusakan di muka bumi ini. Faktor kekerasan agama tidak hanya dipicu oleh faktor eksternal seperti kepentingan politik, ekonomi dan sosial namun faktor internal juga dapat menjadi penyebab kekerasan bernuansa agama itu muncul, misalnya masalah interpretasi atau penafsiran merupakan salah satu masalah utama yang bisa mendorong umat beragama melakukan tindak kekerasan. Juga tidak bisa dipungkiri bahwa ketika agama tampil dalam wajah sebagai organisasi, potensi yang mendorong ke arah konflik dan kekerasan sangat mudah terjadi.

Di dalam agama Kristen, dapat ditemukan bahwa Alkitab memperlihatkan adanya tindakan yang bernuansa "kekerasan" atas nama agama. Perjanjian Lama melalui kisah penumpasan Yerikho yang mana Yosua dan bangsa Isarel menumpas dengan mata pedang segala sesuatu yang di dalam kota itu, baik laki-laki maupun perempuan, baik tua maupun muda, sampai kepada lembu, domba dan keledai" memperlihatkan bagaimana Yosua menumpas kota Yerikho yang tentunya menggunakan tindakan "kekerasan" (menumpas dengan pedang) yang berdasar pada perintah Tuhan, dan jika hal tersebut dipahami sepintas maka akan memunculkan pemahaman bahwa Tuhan mengizinkan tindakan kekerasan. Pertanyaan yang muncul kemudian ialah apakah benar-benar Allah mengizinkan tindakan penumpasan (pembunuhan) dilakukan oleh manusia?

Penumpasan yang dilakukan oleh Yosua terhadap kota Yerikho tidak bisa dilepaskan dari janji yang Tuhan berikan kepada bangsa Israel bahwa bangsa Israel 
akan menduduki suatu negeri yaitu Kanaan, sebuah negeri yang baik, yang berlimpah susu dan madunya (bnd. Im 20:24). Kanaan merupakan negeri di mana Allah akan memberi mereka (bangsa Israel) rasa aman dari musuh-musuh mereka (bnd. Ul 26:110) tetapi negeri itu tidak hanya akan menjadi sebuah berkat, melainkan akan menjadi sebuah tantangan. Dalam rangka menduduki tanah perjanjian tersebut, maka bangsa Israel harus berhadapan dengan berbagai tantangan yang ada dan salah satunya ialah penduduk Kanaan yang adalah penduduk yang telah hidup lama dan menetap di negeri itu. Pertanyaannya ialah bagaimana kemudian bangsa Israel menyingkirkan penduduk di negeri Kanaan? Alkitab Perjanjian Lama khususnya dalam kitab Yosua menjelaskan bahwa cara bangsa Israel untuk merebut dan menduduki tanah perjanjian tersebut adalah dengan cara "kekerasan" yaitu menumpas negeri tersebut, namun ada satu hal yang menarik perhatian, yaitu penumpasan yang dilakukan oleh bangsa Israel (di bawah pimpinan Yosua) dikatakan bahwa atas perintah Tuhan. Suatu hal yang paradoks karena Allah adalah kasih namun juga mengijinkan suatu tindakan pembunuhan, mungkinkah Allah membiarkan ada orang yang boleh dibinasakan dan ada yang diistimewakan?

\section{Metode Penelitian}

Metode penelitian dalam artikel ini adalah analisis teks dengan pendekatan kritik narasi atas Yosua 6:1-27 untuk memahami teks tersebut dan menerapkannya dalam konteks kekinian. Analisis naratif merupakan cabang dari kritik sastra yang mencoba untuk mendekati teks dengan menggunakan struktur penyusunan suatu kisah yang terdiri atas alur cerita, tokoh, dan plot. Dengan metode ini, pembaca masa kini dapat berkontak langsung dengan cerita dan dunianya jika pembaca menghidupkan cerita tersebut melalui penghayatan dalam pembacaan cerita. Analisis atas sebuah narasi memiliki dua aspek, pertama adalah aspek puitis (mempelajari dimensi seni atau suatu cara penulis untuk membentuk teks), kedua ialah makna (untuk menemukan kembali pesan yang dikomunikasikan penulis).

Dalam konteks kitab Yosua 6 ini, penulis menggunakan pendekatan kritik naratif untuk melihat pesan yang hendak disampaikan dalam narasi penaklukkan kota Yerikho dengan melihat narasi penaklukkan secara keseluruhan. Penulis menggunakan kritik narasi karena pendekatan ini membantu menegaskan sejarah serta membantu dalam menganalisis cerita yang dituturkan secara spesifik karena dalam pendekatan ini halhal berkaitan dengan narasi atau cerita (cerita yang terdiri dari alur dan adeganadegan, tokoh dan penokohan, latar waktu dan tempat; dan penuturan yang terdiri dari gaya penceritaan dan sudut pandang) akan dianalisis.. Untuk mencapai hal tersebut, maka diperlukan pembagian atas beberapa adegan yang terjadi dalam narasi/teks yang ada. Dalam narasi Yosua 6:1-27 itu sendiri, mengisahkan secara sistematis tentang suatu peristiwa penumpasan tanah Kanaan sehingga memudahkan pembaca untuk bisa mengerti tentang narasi yang sedang berjalan. Berikut penulis menyajikan beberapa adegan dalam narasi Yosua 6. 
Adegan A : Kondisi terkini kota Yerikho saat bangsa Israel hendak memasuki wilayahnya. Ayat 1

Adegan B : Pesan yang disampaikan Tuhan kepada Yosua mengenai penaklukkan kota Yerikho dan diteruskan oleh Yosua kepada bangsa Israel. Ayat 2-7

Adegan C : Tindakan Yosua dan bangsa Israel dalam mengeksekusi perintah Tuhan (mengelilingi tembok Yerikho tujuh kali pada hari yang ketujuh, meniup sangkakala, bersorak, memasuki kota Yerikho dan menumpas isi kota kecuali Rahab). Ayat 8-25

Adegan D : Bangsa Israel berhasil menduduki kota Yerikho sehingga Yosua mengeluarkan kutukan terhadap siapa saja yang akan membangun kembali kota itu. Ayat 26-27.

\section{Tafsiran Yosua 6:1-27}

Jika membaca bagian teks ini secara tidak hati-hati, maka akan menimbulkan pemahaman yang ambigu terhadap sikap Tuhan yang membiarkan terjadinya suatu tindakan penumpasan dilakukan oleh umat Israel. Disatu sisi pembaca akan digiring pada pemahaman bahwa Tuhan mengasihi umat-Nya, namun dilain sisi, pembaca juga akan digiring pada argumentasi bahwa Tuhan-pun ternyata membiarkan kekerasan dilakukan oleh umat-Nya. Olehnya, penulis mengajak pembaca untuk memperhatikan kata "kherem atau mengkhususkan dengan cara dimusnahkan" dalam narasi ini untuk memahami tindakan Yosua dan bangsa Israel saat itu.

Kata mengkhususkan berasal dari kata Ibrani గุด yaitu kherem yang merupakan kata benda absolut dan memiliki arti (sesuatu yang) dikhususkan (bagi TUHAN), dan biasanya untuk dimusnahkan. Istilah pengkhususan dalam tradisi dibeberapa bangsa di Timur Tengah kuno merupakan hal yang menjadi kebiasaan, pasalnya ada yang mempersembahkan manusia dan harta benda serta tawanan kepada dewa-dewa mereka. Kherem juga memiliki kesamaan dengan bahasa Arab yaitu haram sehingga dapat dikatakan bahwa kota Yerikho disita TUHAN sehingga segala isinya menjadi haram bagi bangsa Israel dan untuk mencegah agar objek (barang atau manusia) tidak digunakan secara umum olehnya itu narator dalam teks tersebut menjelaskan obyek tersebut harus ditetapkan untuk dimusnahkan. Obyek yang ditentukan untuk dihancurkan (kherem) adalah objek yang berdosa dimana mereka pantas dan layak menerima hasil dari tindakan mereka, yaitu kematian. Yosua memerintahkan kepada bangsa Israel agar mereka menjaga diri terhadap obyek yang diharamkan (seperti yang dimaksud dalam di atas), karena apabila hal tersebut dilanggar, narator menyampaikan bahwa akan datang kemusnahan atas perkemahan orang Israel dan mencelakakannya. Singkatnya, kata kherem memiliki dua arti yaitu dipisahkan untuk Allah atau ditentukan untuk dibuang, dihancurkan (to be destroyed).

Dalam narasi Yosua 6, kata kherem memiliki arti yang sangat besar. Pengkhususan suatu obyek kepada Tuhan untuk dimusnahkan semata-mata bertujuan untuk menghadirkan konsep kekudusan bagi umat-Nya. Tindakan pemusnahan yang dilakukan oleh 
bangsa Israel dalam konsep kherem ini memiliki tujuan yang betul-betul bermuara pada konsep kekudusan. Konsep kekudusan dapat tercapai jika umat-Nya hidup dalam lingkungan yang kudus, namun dalam tanah perjanjian khsusunya Yerikho terjadi praktik-praktik penyembahan yang tidak berorientasi kepada Allah Israel dan penduduk Yerikho mengeraskan hati untuk tidak mengakui keberadaan Tuhan Allah Israel sehingga konsep kekudusan tidak ada di sana. Olehnya itu, demi terciptanya lingkungan yang kudus Allah memerintahkan untuk menghabisi segala sesuatu yang terlibat dalam praktik penyembahan berhala baik itu subjek maupun objeknya. Dengan kata lain, kherem dalam narasi Yosua 6 ditujukan bagi mereka yang beribadah kepada ilah lain dan kepada mereka yang tidak mengakui keberadaan Allah Israel. Terjemahan Baru Lembaga Alkitab Indonesia memilih kata yang sedikit agak keras untuk memberikan makna terhadap kata kherem tersebut, yaitu menumpas.

Kata menumpas dalam bahasa Ibrani dituliskan kerja hifil waw konsekutif imperfek orang ketiga jamak maskulin. Kata ini memiliki akar kata חרם yang memiliki arti "menumpas atau memusnahkan". Pemusnahan yang dilakukan oleh bangsa Israel bukanlah tanpa sebab, Imamat 27:28-29 menjelaskan bahwa pemusnahan merupakan sutau hukuman yang berasal dari Tuhan dan yang mendapatkan hukuman ialah mereka yang tidak beribadah kepada Tuhan atau menyembah berhala (Ul. 13:12-18). Berangkat dari hal tersebut, maka dapat dikatakan bahwa Yerikho adalah kota yang mempraktikkan tindak penyembahan berhala. Sejarah mencatat bahwa Yerikho secara khusus atau Kanaan secara menyeluruh merupakan bangsa yang mempercayai adanya dewi kesuburan namun mereka tidak menyadari bahwa tindakan mereka adalah tindakan yang bermoral rendah karena dilakukannya praktik pelacuran keagamaan. Dalam sebuah ceramah, Albright dalam buku Pengantar Perjanjian Lama 1 mengatakan bahwa agama Kanaan merupakan agama yang paling bejat di antara agama-agama lain karena dalam agama Kanaan terjadi pelacuran di kuil, pengurbanan anak, dan sebagainya, sehingga pemusnahan orang-orang Kanaan diperlukan sebagai sebuah proses untuk menjaga kemurnian bangsa Israel dengan kata lain bahwa segala hal yang akan membuat bangsa Israel menjauh dari TUHAN, harus dilenyapkan (pada ayat 24 narator menggunakan kata yang kejam yaitu kota tersebut "dibakar").

Kata menumpas dalam narasi ini merupakan suatu tindakan yang bertujuan untuk menghabisi atau meniadakan. Pertanyaan yang muncul kemudian ialah, apakah yang menjadi objek penumpasan ini? Alkitab mencatat bahwa objek-objek yang ditetapkan sebagai objek yang dikhususkan bagi Tuhan untuk dimusnahkan ialah manusia dan benda-benda maupun hewan-hewan ternak (Kel. 22:20; Im. 27:29; Ul. 13:15-17). Gossweiler mengatakan bahwa kherem dipakai untuk menunjukkan objek entah itu barang, entah itu manusia yang dikhususkan bagi TUHAN untuk dimusnahkan atau dibinasakan. Dikhususkan untuk dimusnahkan merujuk kepada manusia, hewan maupun barang sehingga berangkat dari hal tersebut, maka dapat dikatakan bahwa 
kherem adalah mengkhususkan manusia, binatang, dan barang-barang yang ada di dalam kota Yerikho untuk dimusnahkan.

Penumpasan dalam narasi ini berdasar pada perintah Tuhan kepada Yosua dan bangsa Israel, sehingga pengeksekusi perintah tersebut tidak merasa takut, justru sebaliknya bangsa Israel dengan percaya diri bahwa kemenangan ada dipihak mereka, sehingga mereka tetap maju karena mereka percaya bahwa Tuhan yang berjuang dengan mereka. Peristiwa penumpasan dalam narasi ini memiliki tujuan eskatologis yaitu hendak menyelamatkan manusia dari belenggu penyembahan berhala sehingga kerajaan Allah dapat dinampakkan di dunia.

\section{Pembahasan}

\section{Yosua 6:1-27 dan Kekerasan Atas Nama Agama}

\section{Amanat Kitab Yosua}

Dalam kitab Yosua, ada berbagai macam peristiwa-peristiwa yang terjadi terkait dengan pendudukan tanah Kanaan, salah satunya ialah penaklukkan kota Yerikho yang sekaligus menjadi kisah kunci untuk seluruh kitab Yosua karena penaklukkan kota Yerikho sering dikaitkan dengan pemusnahan kota berikutnya (Yos. 8:2; 9:3; 10:1; 28, 30). Peristiwa atau kisah-kisah yang terjadi dalam kitab Yosua jika dipahami secara sepintas maka akan membawa kepada pemahaman yang keliru tentang Allah maupun tindakan dari bangsa Israel, sebab yang berperang bersama orang Israel dan yang memberikan perintah kepada bangsa Israel untuk memusnahkan orang-orang di Kanaan ialah Allah. Perang Tuhan menurut Gossweiller merupakan istilah yang diberikan untuk menggambarkan suatu kisah pemusnahan yang dilakukan oleh bangsa Israel, pemberian istilah itu bukanlah tanpa alasan karena yang menjadi alasan utama pemusnahan itu ialah Allah berada dipihak Israel dan memberikan kemenangan kepada mereka, atau dengan kata lain TUHAN-lah yang menjadi penggerak utama dalam pemusnahan tersebut.

Pemusnahan yang dilakukan oleh bangsa Israel terhadap tanah Kanaan khususnya kota Yerikho merupakan arahan daripada Tuhan itu sendiri, mengapa demikian? Karena bangsa Kanaan merupakan bangsa yang hidup dalam kenajisan melalui penyembahan berhala, dan tindakan-tindakan amoral yang lainnya. Konsep perang (pemusnahan/kherem) ini memiliki kaitan yang kuat dengan kasih Tuhan yang besar bagi umat-Nya dalam rangka memperbaiki tatanan kehidupan manusia. Kisah penumpasan kota Yerikho harus dipahami sebagai sebuah tindakan kasih dari Tuhan kepada manusia, karena Tuhan begitu mengasihi manusia sehingga Ia tidak bisa dan tidak mau toleran terhadap dosa, dan segala perbuatan dosa harus diganjar dengan hukuman yang sepadan. Dengan kata lain kisah tersebut merupakan bentuk penghukuman Allah yang dilaksanakan secara adil terhadap keberdosaan manusia. Olehnya itu, konsep perang Tuhan ini harus dipahami sebagai pertempuran Allah melawan kuasa-kuasa kegelapan yang hendak menghancurkan manusia. Perang atau kisah penumpasan kota Yerikho hendak memperlihatkan bahwa Allah sebagai aktor utama dalam peperangan. Kehadiran Allah sebagai aktor utama dalam perang 
menunjukkan bahwa peperangan dalam Alkitab tidak dimulai dari kehendak manusia, namun dimulai dari Allah, sehingga persoalan penghukuman dan pembebasan bukan menjadi hak manusia tetapi menjadi hak dan tanggungjawab Allah.

Selanjutnya ialah bahwa kitab Yosua memperlihatkan suatu hubungan sebabakibat, maksudnya ialah apa yang dialami oleh bangsa Israel dalam hal ini penyertaan dan kemenangan semuanya disebabkan oleh ketaatan mereka dalam mengikuti perintah Tuhan yang berujung pada kesuksesan mereka dalam menduduki tanah perjanjian. Hal ini memperlihatkan bahwa manusia (bangsa Israel) tidak bisa menyelamatkan diri mereka sendiri (dalam peperangan) tanpa campur tangan Tuhan, olehnya itu merupakan sebuah kewajiban dan keharusan bagi bangsa Israel untuk memilih Tuhan dan menolak ilah-ilah lain yang disembah oleh bangsa-bangsa kafir, termasuk Kanaan. Penyelamatan dan penyertaan yang dilakukan Allah semata-mata didasarkan pada kasih Allah kepada ciptaan-Nya, meskipun demikian, Allah tetap mewajibkan umat-Nya untuk hidup dalam kekudusan dengan menjauhkan diri dari penyembahan berhala, namun jika syarat tersebut dilanggar (berpaut kepada Baal), maka bangsa Israel akan mendapat ganjarannya yaitu hukuman seperti yang dialami bangsa-bangsa lain yang jauh dari Tuhan.

\section{Reinterpretasi Teks sebagai Upaya Mencegah Tindak Kekerasan Atas Nama Agama}

Pada dasarnya agama merupakan tuntunan bagi umat manusia yang berisi aturanaturan tentang tata cara membangun relasi yang baik dengan sesama dan kepada Tuhan yang terdiri dari empat komponen, yaitu emosi keagamaan, sistem kepercayaan yang mengandung keyakinan, sistem upacara religius, dan kelompok-kelompok religius yang diharapkan mampu mengantar manusia kepada pengenalan yang benar tentang agama yang merupakan tuntunan kehidupannya. Pada hakekatnya, agama memiliki tujuan yaitu membangun tatanan kehidupan manusia kearah yang lebih baik dalam segi iman, moral, maupun pengetahuan. Dengan kata lain, agama menghendaki yang namanya pertumbuhan dan kebaikan dan menolak yang namanya tindakan yang dapat merugikan diri sediri dan orang lain.

Kekerasan yang mengatasnamakan agama, merupakan suatu realita pahit dalam perkembangan keagamaan, hal ini disebabkan karena para pemeluk-pemeluk agama yang memiliki jiwa radikalisme yang sangat kuat sangat sulit untuk dikendalikan untuk tetap berada dalam jalur yang benar sesuai dengan tuntutan agama masing-masing. Fenomena kekerasan atas nama agama tidak boleh dilihat sebagai sesuatu yang berdiri sendiri atau murni berasal dari dalam agama itu sendiri, melainkan harus pahami sebagai suatu hasil negatif dari berbagai faktor. Misalnya faktor kemiskinan, kepincangan sosial dengan sistem kekerasan, kolusi, dan tindakan-tindakan lain yang berujung pada kehidupan yang tidak stabil dalam membangun manusia yang lebih baik. Secara logika manusia, agama apapun tidak akan bisa menjauhkan diri dari tindak kekerasan dan justru mau tidak mau, suka tidak suka harus kokoh menghadapi tantangan kekacauan dalam tatanan kehidupan manusia. Tindakan kekerasan atas 
nama agama yang dilakukan oleh kelompok-kelompok tertentu setidaknya memiliki alasan untuk bertindak, diantaranya ialah mereka menganggap bahwa agama harus mengambil langkah secara radikal untuk melakukan perlawanan terhadap berbagai macam ancaman yang akan mengganggu agama tersebut dengan kata lain modernitas dan sekularisasi dianggap tidak penting, selanjutnya mereka akan menganggap bahwa pluralisme adalah suatu paham yang keliru dalam agama, dan yang terakhir ialah persoalan pengetahuan secara historis dan sosiologis telah membawa manusia semakin jauh dari doktrin agama.

Kekerasan yang mengatasnamakan agama merupakan momok yang sangat menakutkan bagi kelangsungan agama-agama, karena sejatinya agama harus mengajarkan nilai-nilai luhur, namun dengan perbuatan yang tidak bertanggungjawab maka agama diubah menjadi institusi yang tidak sejalan dengan norma-norma agama itu sendiri. Olehnya itu, kekerasan dalam agama harus dipahami sebagai hukuman yang dikenakan untuk komunitas umat yang terbukti tidak mematuhi perintah Tuhan sebagaimana yang diatur dalam ajaran agama masing-masing. Misalnya, yang terjadi kepada bangsa Kanaan (Yerikho) yang mendapat hukuman dari Tuhan berupa kherem karena mereka tidak hidup sesuai dengan perintah Tuhan. Ganjaran yang demikian adalah sah-sah saja mengingat yang memberikan hukuman ialah Sang Pemilik kehidupan.

Kisah penumpasan yang dilakukan oleh Yosua dan bangsa Israel, disatu sisi memperlihatkan bahwa adanya sebuah tindakan "kekerasan" yang dilakukan oleh Yosua dan bangsa Israel, hal ini diperkuat dengan suatu tindakan yang mereka lakukan yaitu menumpas segala isi kota Yerikho dengan mata pedang serta membakar habis kota itu atas dasar perintah Tuhan. Jika dipahami sepintas, maka akan menggiring kita kepada pemahaman bahwa Tuhan mengizinkan suatu tindakan kekerasan karena membiarkan pembunuhan terjadi di Yerikho. Namun, narasi itu tidak bisa dilihat dari satu sisi saja, namun harus dilihat secara historis dan menyeluruh karena jika ditelusuri, maka akan ditemukan bahwa penumpasan itu bukanlah sekadar penumpasan yang dilakukan tanpa alasan melainkan ada alasan yang kuat dibalik penumpasan itu.

Kitab Yosua mencatat bahwa bangsa Yerikho telah hidup dalam kenajisan akibat dari penyembahan berhala yang mereka lakukan dan hal itu merupakan suatu kekejian bagi Tuhan sehingga harus dilenyapkan, atau dengan kata lain tanah Kanaan (termasuk Yerikho) harus menjadi tanah yang kudus sebab umat Allah yang kudus harus hidup bersama dengan Allah di sana, sehingga setiap tindakan yang tidak mendukung konsep tersebut harus mendapat ganjaran yaitu pemusnahan secara total segala makhluk hidup yang ada di tanah tersebut. Pemusnahan total Kanaan bukan hanya untuk menjaga Israel agar tidak tercemari oleh pengaruh dan gaya hidup bangsa Kanaan namun juga sebagai sebuah bentuk keputusan hukum yang Allah sudah tetapkan atas Kanaan. Konsep perang (penaklukkan yang berujung pemusnahakn kota Yerikho) dalam konteks Yerikho tidak bisa dilepaskan dari kehidupan bangsa Israel Kuno yang 
menjadikan perang sebagai ibadah kepada Tuhan, dengan kata lain ketika mereka melakukan perang (menumpas ataupun menaklukkan) maka hal tersebut dilihat sebagai sebuah ketaatan dan pengabdian kepada Tuhan yang mereka sembah.

Peristiwa perebutan tanah Kanaan merupakan suatu proses untuk mewujudnyatakan kerajaan Allah ditengah-tengah dunia dan Israel secara khusus terkesan dilakukan dengan kekuatan fisik melalui perang. Namun, meskipun demikian tujuan utama yang hendak disampaikan bukan bersoal pada kisah penumpasan namun yang hendak ditunjukkan ialah kuasa kejahatan yang harus ditumpas sebab itulah musuh Allah. Tuhan menyapu bersih penduduk negeri Yerikho sebagai upaya agar umat Israel tidak dinajiskan oleh penyembahan berhala bangsa Kanaan dan rencana besar Allah tidak terkandaskan. Selain itu, konsep perang (pemusnahan) dapat juga dikaitkan dengan keadilan Allah kepada umat-Nya. Dalam hal ini, perang dijadikan alat untuk secara adil memisahkan antara yang kudus dan tidak kudus atau yang layak diselamatkan dan yang layak untuk dimusnahkan. Sehingga kisah penumpasan Yerikho ini tidak dapat digolongkan sebagai tindakan kekerasan yang mengatasnamakan agama.

Alkitab Perjanjian Lama (Kitab Yosua) bukanlah merupakan kitab yang berbicara tentang kekerasan atas nama agama sehingga jangan dipahami sebagai kitab yang pro terhadap kekerasan. Ada banyak penafsir yang menafsirkan kitab Yosua ini sebagai kita yang pro terhadap kekerasan, misalnya Christian Gossweiler yang menafsirkan kitab ini sebagai kitab yang pro terhadap kekerasan, secara sepintas memang kitab ini berbicara tentang penumpasan (kekerasan) namun kisah penumpasan itu sebaiknya jangan dilihat secara terpisah dari keseluruhan narasi penaklukkan Yerikho karena tindakan penumpasan yang dilakukan bangsa Israel adalah memiliki alasan yang jelas dan tujuannya bersifat soteriologis untuk kepentingan penegakan kerajaan Allah. Lady Paula pun pernah mengatakan dalam sebuah hasil penelitiannya bahwa pada saat kerusuhan meledak di Halmahera, jemaat-jemaat Kristen saat itu sempat membaca teks dalam Yosua khususnya tentang peperangan dan menjadikan teks itu sebagai legitimasi mereka untuk ikut serta dalam peperangan saat tersebut.

Penafsiran-penafsiran yang seperti ini seharusnya mendapat perhatian yang serius, karena jika demikian yang terjadi maka akan muncul doktrin yang mengatakan bahwa Allah menghendaki tindakan pembunuhan diberlakukan dalam semua konteks. Padahal kata kherem dalam kisah Yosua 6 memiliki hanya berlaku pada konteks Yerikho dan hanya eksis pada zaman itu, juga kata tersebut memiliki kandungan spiritual yang besar karena memiliki tujuan yang bersangkutan dengan Tuhan yang Mahakuasa. Tindakan penumpasan tidak dimulai dengan inisiatif manusia namun murni berasal dari inisiatif Tuhan. Olehnya itu pada zaman sekarang ini, kisah penumpasan harus dilihat sebagai sebagai peperangan Allah untuk mengalahkan kuasa kegelapan yang hendak merusak umat yang dikasihi-Nya. Dalam konteks Yosua dijelaskan bahwa semakin tinggi Tuhan ditonjolkan maka yang terjadi ialah frekuensi umat dalam melakukan tindakan pemusnahan semakin tinggi dan juga sikap yang diperlihatkan umat adalah sikap taat dan 
setia. Sehingga dapat dikatakan bahwa teks-teks dalam Yosua harus dilihat sebagai bukti ketaatan manusia dalam merespon perintah Tuhan.

Penaklukkan atau pemusnahan yang terjadi saat itu tidak pernah berhenti pada tindakan pembunuhan semata namun dalam konteks PL penumpasan yang dilakukan selalu memiliki goal yang bersifat soteriologis demi pengudusan dan keselamatan umat pada masa itu. Pembenaran terhadap tindak kekerasan (penumpasan) dalam konteks Yosua, hanya berlaku saat itu demi mendukung terwujudnya rencana besar Allah yakni lahirnya bangsa Israel sebagai bangsa yang besar. Penumpasan yang terjadi saat itu murni merupakan kehendak Allah yang sama sekali tidak dicampuri oleh hawa nafsu manusia. Perang itu tidak jahat, namun yang jahat ialah motivasi dari para pelaku perang. Persoalan kekerasan agama merupakan permasalahan yang begitu kompleks dan terlihat sulit untuk dihindari, namun meskipun demikian fenomena kekerasan atas nama agama ini menarik perhatian sejumlah kalangan khususnya para pemuka agama ataupun pemikir agama untuk memberikan solusi untuk mengurangi atau bahkan bila mungkin menghapus stigma buruk tentang agama yang berkembang akibat tindak kekerasan.

Beberapa solusi yang ditawarkan ialah, pertama menghilangkan Fanatisme yang ekstrim. Jika dilihat dari arti katanya, maka dapat dikatakan bahwa fanatik merupakan tindakan yang wajar untuk dilakukan karena berhubungan dengan sikap atau perilaku yang menunjukkan ketertarikan terhadap sesuatu, namun sangat disayangkan bahwa arti kata itu kemudian disalah artikan oleh golongan-golongan tertentu yang terlalu berlebihan terhadap agamanya sehingga menutup diri dengan segala hal yang berasal dari luar agama yang dianutnya. Jika seseorang telah memiliki faham seperti ini dalam sebuah agama, maka agama tersebut akan digiring kepada suatu tindakan eksklusivisme agama. Sikap fanatik seharusnya hanya ditujukan kepada Allah sebagai sumber kebenaran. Kedua, harus dilakukan reinterpretasi terhadap doktrin-doktrin agama. Tidak dapat dipungkiri bahwa dalam praktek kehidupan beragama, terdapat berbagai macam doktrin-doktrin yang ditawarkan penafsir demi memudahkan pemeluk agama untuk hidup dalam spiritual yang baik. Namun dalam realitas yang ada, ditemukan bahwa masih banyak juga doktrin yang justru menawarkan tindakan kekerasan sebagai sebuah ibadah atau kebaktian kepada Tuhan, sehingga hal ini memicu terjadinya konflik antara pemeluk agama. Olehnya itu sangat diperlukan interpretasi atas interpretasi lapis pertama agar doktrin yang dilakukan sekarang membawa manusia kepada kesejahteraan hidup.

Ketiga ialah membangun dialog antar agama yang pluralistik dan bertanggung jawab. Yang tentunya dengan tujuan agar umat beragama saling mengerti dan memahami serta membangun komitmen bersama untuk kesejahteraan umat manusia maupun lingkungan dan hal tersebut dapat tercapai jika dialog tersebut didasari pada pengakuan tentang adanya pluralitas agama-agama. Dengan kata lain, setiap agama mempunyai rujukan kebenaran sendiri sehingga berhak untuk mengembangkan dirinya. Olehnya itu, tidak boleh ada agama yang menyebut diri sebagai yang paling 
benar dari yang lain. Dasar dari setiap agama ialah Allah sehingga agama seharusnya berorientasi pada Allah, mendengar, dan mengikuti-Nya. Hidup beragama jangan hanya berorientasi pada aspek mengejar kebahagiaan jiwa secara personal, namun juga harus merangkul penghargaan terhadap realitas manusia sebagai sesama makhluk ciptaan Tuhan.

\section{Kesimpulan}

Kisah penumpasan yang dilakukan oleh Yosua dan bangsa Israel harus dipahami sebagai cara atau strategi Allah dalam menghukum bangsa-bangsa yang tidak taat kepada-Nya serta menjauh dari ketetapan-ketetapan-Nya. Allah adalah Kudus dan Ia menghendaki agar ciptaan-Nya (manusia) terus hidup dalam bingkai kekudusan. Segala yang menghalangi keinginan-Nya harus dilenyapkan agar tidak menjadi penghalang bagi umat yang lain untuk hidup dalam kekudusan. Perspektif konteks zaman pada saat itu melihat kekerasan sebagai hal yang biasa terkhusus dalam konteks Yosua tindakan pemusnahan tersebut dilihat sebagai proses penyucian dan pengudusan untuk mempersiapkan Israel untuk menjadi bangsa yang beradab atau dengan kata lain mempersiapkan bangsa Israel menjadi bangsa yang punya aturan. Keberhasilan bangsa Israel merebut kota Yerikho dilihat sebagai sebuah kemenangan kerajaan Allah atas kuasa iblis.

Konsep penumpasan yang terjadi dalam narasi penaklukkan kota Yerikho merupakan kehendak dari Allah dan manusia hanya berperan sebagai pelaksana kehendak tersebut, sehingga hal ini memperlihatkan bahwa tindakan penumpasan adalah tindakan yang sah dilakukan saat itu demi sebuah tujuan eskatologis. Tindakan penumpasan dalam teks Yosua 6 ini harus dipahami sebagai tindakan yang berlaku pada zamannya, karena dengan pemahaman demikian, maka dalam menafsirkan teksteks seperti itu penafsir tidak mengambilnya secara mentah namun perlu mendapat sentuhan analisa yang mendalam. Dalam tradisi yang ada saat zaman Yosua, menumpas atau melenyapkan sesuatu yang dianggap sebagai musuh Allah atau yang memberontak kepada Allah merupakan tindakan yang sah karena dianggap sebagai ibadah dan wujud ketaatan kepada Allah. Sehingga dapat dikatakan bahwa kitab Yosua ini sama sekali tidak memiliki hubungan dengan kekerasan atas nama agama seperti yang terjadi akhir-akhir ini dan tidak boleh dijadikan sebagai legitimasi untuk melakukan tindak kekerasan. Konsep peperangan dalam Perjanjian Lama yang sangat dekat dengan fisik telah mendapat makna yang baru dalam terang Perjanjian Baru, kini konsep perang yang hendak dialami oleh orang Kristen ialah peperangan secara rohani, yakni melawan kuasa-kuasa iblis yang berusaha menciptakan permusuhan diantara manusia.

\section{Referensi}

Baker, D.L. dan A.A. Sitompul. 2010. Kamus Singkat Bahasa Ibrani, Jakarta: BPK Gunung Beuken, Wim dan Karl Yosuaef Kuschel. 2003. Agama sebagai Sumber Kekerasan?. Yogyakarta: Pustaka Pelajar.

Dyrness, Willian A. 2001. Agar Bumi Bersukacita. Jakarta: BPK Gunung Mulia. 
Gossweiler, Christian. "Yerikho Dibumihanguskan: Cerita Kekerasan dalam perjanjian Lama"Forum Biblika: Jurnal Ilmiah Populer. No. 26 (2012): 6.

Green, Denis. 2012. Pengenalan Perjanjian Lama, Malang: Gandum Mas.

Hidayatullah, Syarif. 2013. Agama dan Kekerasan, Yogyakarta: Badan Penerbit Filsafat UGM.

Intan, Benyamin F. "Kekristenan dan Violence: Just War Dan Tradisi" Societas Dei: Jurnal Kekristenan dan Viloence. Vol. 1 No. 1 (2014): 41.

Karman, Yonky. 2004. Bunga Rampai Teologi Perjanjian Lama, Jakarta: BPK Gunung Mulia.

Knitter, Paul F. Satu Bumi Banyak Agama, Jakarta: BPK Gunung Mulia.

Kurnia Y, Yuangga. "Fenomena Kekerasan Bermotif Agama di Indonesia" Kalimah: Jurnal Studi Agama dan Pemikiran Islam, Vol. 15 No. 2 (2017): 212.

LaSor, W.S, D.A. Hubbard, dan F.W.Bush. 2014. Pengantar Perjanjian Lama 1. Jakarta: BPK Gunung Mulia.

Osborne, Grant R. Spiral Hermeneutika: Pengantar Komprehensif bagi Penafsiran Alkitab. Surabaya: Momentum.

Panda, Herman P. 2013. Agama-agama dan dialog antar-agama dalam pandangan Kristen, Maumere: Ledalero.

Pfeiffer, Charles F. dan Everett F. Harrison. 2014. The Wyliffe Bible Commentary: Tafsiran Alkitab Wycliffe Volume 1 Perjanjian Lama: Kejadian-Ester, Malang: Gandum Mas.

Riyanto, Armada. 2010. Dialog Interreligius. Yogyakarta: Kanisius.

Santoja, Jakub. 1993. Peran Eksegese Narasi dalam Studi Teologi" dalam Gema Duta Wacana 45. Yogyakarta: Fakultas Teologi UKDW

Setyawan, Yusak B. 2017. Perdamaian dan Keadilan: Dalam Konteks Indonesia yang Multikultural dan Beragam Tradisi Iman. Jakarta: BPK Gunung Mulia.

Tule, Philipus.2016. Ilmu Perbandingan Agama-agama, Maumere: Ledalero.

Wiersbe, Warren W. 2012. Hidup Bersama Firman: Pasal demi pasal seluruh Alkitab Yosua-Ester, Yogyakarta: Yayasan Gloria.

Yewangoe, A.A. 2006. Agama dan Kerukunan. Jakarta: BPK Gunung Mulia. 